\title{
RAPGEFL1 wt Allele
}

National Cancer Institute

\section{Source}

National Cancer Institute. RAPGEFL1 wt Allele. NCI Thesaurus. Code C52818.

Human RAPGEFL1 wild-type allele is located within 17q21.1-q21.2 and is approximately $17 \mathrm{~kb}$ in length. This allele, which encodes Rap guanine nucleotide exchange factor-like 1 protein, may be involved in the modulation of Ras-dependent signaling pathways. 